\title{
Determining factors of women's careers in management: A typology proposal
}

\author{
Cristina Cachón (iD \\ Universidad Rey Juan Carlos (Spain) \\ cr.cachon@alumnos.urjc.es
}

\section{Abstract}

Purpose: The objective of this paper is to identify a typology of the factors that determine the professional career of women in managerial positions, based on the different contributions made to the literature.

Design/methodology: A systematic literature review has been carried out, using Google Academic portal searches and ABI, SCOPUS and WOS databases, allowing the analysis of several articles.

Findings: The professional career of women in managerial positions is determined by several factors that motivate or limit their professional development. These factors are commonly listed and described in the literature. However, there is no generally accepted classification of these factors. Therefore, as a result of this work, a typology is proposed that allows the classification of determining factors affecting the professional careers of women directors.

Practical implications: This work has important future implications for researchers who intend to empirically contrast the proposed classification and analyze the factors in depth. It also has implications for business executives whose objective is to promote the role of women in positions of responsibility within organizations.

Originality/value: This paper highlights the identification of the typologies that are necessary for the development of theories and research in the social sciences. It is important to categorize and describe factor classifications in order to understand them better, so as to be able to extrapolate a common theory for other research and to propose solutions in the business environment that allow breaking with the glass ceiling in senior management positions.

Keywords: Management career, Women in management, Leadership, Determining factors, Typology

Jel Codes: J16, J24, J71, M12 


\section{Background}

Traditionally, the labor relationship was based on the father, the head of the family, who worked to provide sustenance for the family, while the woman was in charge of the home and taking care of the children and dependents. In recent times, numerous changes have come about on an economic, social, political and technological level that have generated a new work-family relationship (Álvarez \& Gómez, 2010). This new binomial, work-family, refers to a new relationship based on the double responsibility in which both men and women have to take on tasks in the work environment and in the family setting.

One of the main manifestations of this binomial has been the incorporation of women in the labor market. This change means an unstoppable dynamic for the progressive equality between men and women (Sabater, 2014). The result of this binomial is a double-edged sword, as it has both a positive and negative sense.

The fact that women are joining the world of work is considered to be positive, as it strengthens their personal and professional development, adds more talent to organizations and contributes to economic and social wellbeing; as it increases the active population, families have more money entering the homes from the new job, and as a result, along with the greater purchasing power, consumption increases (Álvarez \& Gómez, 2010). In terms of the negative aspect, it can be added that, in light of the difficulty of bearing the double responsibility of work and family, far from achieving equality, men and women are subjected to the institutionalization of the double work day: on the job and at home (Aguirre \& Martínez, 2006).

Research has studied the repercussion in different areas of life of the incorporation of women into the world of work, as this is the group most affected by the work-family binomial. First of all, from the social and educational dimension, the educational level of women has increased, as has the need to see themselves involved in the business world, either out of a sense of satisfaction and personnel development or due to the need to earn a double income in order to maintain the home (Sabater, 2014). Society is increasingly more aware of the need for men to collaborate in household chores in favor of this binomial.

Secondly, in the economic and organizational dimension, Aguirre and Martínez (2006) maintain that measures are being taken to favor the insertion of women in the labor world, such as the lengthening of the school day, the increase in extracurricular activities or daycare centers to make it possible to facilitate and adapt schedules to a greater extent to women's business schedules. However, other studies detect a certain rigidity in the organizational structure of businesses that sometimes requires them to renounce one of the halves of the binomial, based on the time and/or economic availability of families (Durán, 1997).

Thirdly, in the area of gender, it is important not to forget the stereotypes that assign to men the roles of production and confine women to the area of caregiving and household chores (Durán, 1997). However, there are numerous laws that prohibit discrimination. Articles 20 and 21 of the Charter of Fundamental Rights of the European Union recognize the principle of equality before the law and non-discrimination based on gender. In turn, the European Directives have stressed the need for the approximation of the legislations of the Member States to the application of the principles of equality in relation to worker compensation among men and women, as well as access to employment, training and working conditions (Directiva 75/117, 1975; Directiva $76 / 207,1976)$. In spite of all the legal efforts in this regard, this cliché or stereotype will mark the development of a woman's professional career, since it is precisely the difference in gender that determines the economic and professional inequality between men and women (Wirth, 2001). This results in many women eventually renouncing their professional careers or having a family. In the latter case, the direct effect of this is a clear decrease in the birth rate, as shown by 2015 data from the INE, when the average number of children per woman in Spain was 1.33 (INE, 2016).

Finally, from the public powers, an effort can be seen to develop public policies that help families with the professional development of women (Guirao, 2011). In terms of work, changes have occurred that have permitted the increase in the presence of women in the professional arena. For example, family care leave is regulated, telecommuting has been introduced, which provides greater flexibility in terms of work hours and places, self-employment is promoted with tax incentives and hiring is encouraged with discounts on Social 
Security contributions and different contracting modes (i.e., full and part-time), among other measures (Cánovas, Aragón \& Rocha, 2005; Belzunegui, 2008; Martínez \& Osca, 2004). However, all this does not appear so obvious to the senior management of large companies, since the political efforts are concentrated at low levels of the organizational pyramid and there are scarce measures to facilitate access to senior management positions and to promote the work-family balance at managerial levels.

Many studies consider the factors generically and insist on correlating academic production and institutional practice (Hopkins \& Bilimoria, 2008; Sullivan \& Mainiero, 2008). In other words, many studies reflect the limitations that are found by women over the course of their professional careers (Rincón, González \& Barrero, 2017) and they thus claim the need for governments to take sides and establish measures and institutional solutions (Lucia-Casademunt, Ariza-Montes \& Morales Gutiérrez, 2013; Ramos, Barberá \& Sarrió, 2003; Moncayo Orjuela \& Zuluaga, 2015). However, in spite of the vast academic production in relation to the barriers and factors that facilitate the professional career of women, there are still few articles that reflect a classification of the factors that would permit them to be grouped in a unanimous and coherent manner. While it is very important to know which are the factors that directly affect women in their careers, it is equally important to group the factors into types in order to better understand each of them individually and frame them within a certain context and circumstances.

It therefore becomes necessary to classify these factors these factors that mark the professional development of women in managerial positions in order to understand them better, to get to the cause or origin of each, and thus be able to present solutions and measures that are favorable for women. For this reason, the aim of this work is:

- to propose a classification of the factors that encompasses the criteria of the authors who establish classifications.

- to establish a typology model common to all and that can be empirically tested in future research works.

This work is structured as follows: first of all, it describes the methodology used, secondly, it describes the results and finally, it draws conclusions and recommends future lines of research.

\section{Methodology}

A typology is conceptually defined as "ideal types" that present a combination of common attributes (Doty \& Glick, 1994). Dess, Newport and Rasheed (1993) consider that the typologies must refer only to a system of conceptual classification from a theoretical perspective. For this reason, the researcher traces a conceptual framework developed "a priori," and once designed, it would be empirically tested (Cousté, 1997). The typologies are a mechanism that is used to describe structures, strategies, characteristics and environments or contexts. Any typology is characterized by the following keys aspects (Bozart \& McDermott, 1998):

- The typologies must offer a theory that can be extrapolated and applied individually (Doty \& Glick, 1994).

- Any theory must specify the individual dimensions of which it is constituted (Miller, 1996).

- The typologies are considered to be theoretical statements and from them, hypotheses can be designed that can be empirically tested (Doty, Glick \& Huber, 1993; Richardson, Taylor \& Gordon, 1985; Kotha \& Vadlamani, 1995).

The typologies, in short, are merely conceptual, but cannot be fully developed until they have been validated from an empirical perspective (Meyer, Tsui \& Hinings, 1993). This study therefore intends to define an ideal classification of the factors that determine the professional development of women in managerial roles. In light of the complexity of their empirical validation, it is also necessary to point out that there are always residual aspects to be considered. This is an option that this typology cannot account for in some cases (Cousté, 1997). 
For the analysis of the factors, a systematic literature review methodology has been applied, which is taking on increasingly greater importance in the social sciences (Webster \& Watson, 2002; Geraldi, Maylor \& Williams, 2011).

\subsection{Phases of the systematic literature review methodology}

The methodology used for this systematic literature review has been divided into two phases. The first phase is dedicated to the identification and selection of relevant studies, while the second phase analyzes these studies (Pateli \& Giaglis, 2004).

\subsubsection{Identification and selection phase}

For the individual search of the articles, searches were conducted, filtering by the document title and abstract, in the Google Scholar portal that covers a large part of the journals and electronic publications (Berkovich, Leimeister \& Krcmar, 2011), as well as the ABI, SCOPUS and WOS databases. These searches were conducted during the months of January-October 2017.The analyzed period is from 2000 to October 2017.This period was chosen because according to Selva, Sahagún and Pallarès (2011) in the bibliometric analysis of the career and access of women to managerial positions, from the start of the century on, "the topic has drawn more interest" and nearly $78 \%$ of the articles published on this topic are from after the year 2000 .

In the search, the following expressions or combinations of key words were entered, since they are the ones that are the most repeated in scientific studies on women in management: women executives factors, women directors, factors, gender career, woman career development, woman entrepreneurship, diversity on board of directors, women management, women leadership. These terms were searched for in both the title of the document and in the abstract.

To explain this search in greater detail, it is considered relevant to describe the inclusion and exclusion criteria (Marín-García \& Martínez-Tomás, 2016). Among the inclusion criteria were papers published in the ABI, SCOPUS, Web of Science and Google Scholar databases. Also included were articles published between 2000 and 2017 in either Spanish or English. In addition, articles were also considered that contain in their title or abstract the expressions or combinations of key words mentioned above. The exclusion criteria, in turn, ruled out papers published before the year 2000 and in any language other than Spanish or English. Articles were also eliminated that did not contain any type of classification of the factors. Many articles perfectly describe the factors that determine the professional career of women in managerial roles (Kumra, 2010; Festing, Knappert \& Kornau, 2015; Hopkins \& Bilimoria, 2008; Eagly \& Carli, 2007; Cuadrado, 2003; Hafsteinsdóttir, Van del Zwaag \& Schuurmans, 2017; Hancock \& Hums, 2016; Terjesen \& Singh, 2008). However, it was considered important for developing the typology to include exclusively those articles that present some type of classification.

In the selection phase, the criteria followed for selecting the articles was, on the one hand, the requirement that the abstract content must be directly related to the research topic, determining factors of the professional career of women in managerial positions, and on the other hand, the frequency of citations of each article. The results obtained showed:

- A set of articles that analyzed the factors that motivate and limit the professional career of women. These articles are the ones considered in this paper. (50 articles in this category).

- A set of articles on the experience women have at different times of their professional career. (26 articles in this category).

- A set of articles that study women from a sector approach: articles that focus on a specific sector, a specific country, a certain position, etc. (12 articles in this category).

- A set of articles that analyze the professional success of women in quantitative terms or in terms of results. (6 articles in this category). 
- A set of articles that present institutional solutions to promote the presence of women in managerial positions and that favor diversity. (6 articles in this category).

In this research, we have focused on the first set of articles: articles that analyze the factors in general terms. In this process, a total of 50 articles were found that belong to this category.

\subsubsection{Analysis phase}

In the analysis phase, after having carefully read the 50 articles, 24 articles were carefully analyzed, as they were the ones that analyzed the research topic of this study in the greatest depth, were the most cited and the ones that most extensively covered the objectives of this work (Table 1).

\begin{tabular}{|l|r|r|}
\hline Category & Number of articles & Frequency \\
\hline Theoretical or review research & 11 & $45.8 \%$ \\
\hline Quantitative research & 13 & $52.2 \%$ \\
\hline Total & 24 & $100 \%$ \\
\hline
\end{tabular}

Table 1. Article analysis

The 24 articles analyzed correspond to the years 2000-2015.Of the 24 articles, $45.8 \%$ are theoretical or review research (11 articles) and 54.2\% are quantitative research (13 articles).Furthermore, of these 24 articles, only $37.5 \%$ are articles that provide classifications of these factors ( 9 articles). These articles can be found in management-related journals (i.e., Strategic Management Journal, Management Research Review, South African Journal of Economic and Management Sciences, Academia Revista Latinoamericana de Administración, Pensamiento y Gestión) or in journals on psychology (Journal of Business Ethics, Apuntes de Psicología, Anuario de Psicología).

For the analysis of the final 9 articles, a table was created with the following categories to better study them (Marín-García \& Martínez-Tomás, 2016):

- Article: specifying the title of the article, the year and the author. Example: Mensi-Klarbach (2014).Gender in top management research. Towards a comprehensive research framework.

- Objective: a brief description of the objective of the study. Example: to provide an approach to the gender differences on boards of directors.

- Study: indicates the type of study. Example: conceptual study on the role of gender on boards of directors.

- Period of analysis:1984-2014.

- Hypotheses: hypotheses suggested by the relationship between gender and the impact it has on the managerial position. Example: Hypothesis 1: senior managers have a direct impact on the results of an organization; Hypothesis 2: the differences between men and women directly affect work in senior management.

- Results: this device will be used to verify whether the proposed hypotheses have been proven. Example: due to the differences between men and women, a classification of the factors was developed: social, organizational and individual, to understand the impact of gender on senior management positions.

\section{Results. Typology proposal}

In the research reviewed, the factors are analyzed in many different ways. Most of the studies that identify classifications are reviews. In other words, the content of these articles is not empirical and is merely limited to 
performing a review or a disciplined reflection that seeks to examine the published bibliography (Selva et al., 2011).

In these articles analyzed, the factors are classified in very different ways. There are different classifications. On the one hand, factors from the social context, organizational context and individual context are considered (Mensi-Klarbach, 2014).According to the social context, the organizations operate in a certain environment, with certain social circumstances. For example, in the case highlighted by Mensi-Klarbach (2014), special reference is made to vertical and horizontal segregation as a social element that determines the professional career of women. In terms of the organizational context, Acker (2006) establishes that the behavior of organizations and especially boards of directors must take into account the identity of gender equality that is present in society and therefore also in today's organizations. Finally, the individual context is understood as the individual characteristics of people that must be considered, as they have a direct impact on the contribution women in managerial positions make to the organizations (Hambrick \& Mason, 1984).

Another classification of factors would be positive and negative factors (Pletzer, Nikolova, Kedzior \& Voelpel, 2015; Dezsó \& Ross, 2012). This classification stresses the positive or negative impact of the presence of women in senior management positions.

Mention is also made of another typology of factors. Corporate or organizational factors and cultural and behavioral factors have been identified by Oakley (2000). Organizational factors are those that have a direct effect when it comes to recruiting, selecting, retaining and promoting women. Cultural and behavioral factors are social and gender factors based more on stereotypes, power and leadership style than on the organizational policies in question.

However, generally speaking, most authors differentiate between internal and external barriers (Moncayo Orjuela \& Zuluaga, 2015; Hawley, Torres \& Rasheed, 1998; Swanson \& Witke, 1997; Ramos et al., 2003; de Anca \& Aragón, 2007; Agut Nieto \& Martín, 2007). To start with, external barriers are understood as all those barriers with a sociodemographic and contextual component that establish the organizational culture and the generic differences in leadership style and gender stereotypes. De Anca and Aragón (2007), in turn, explain external factors as social barriers based on stereotypes, as organizational barriers based on the organizational culture and identity. Secondly, internal barriers are understood as all those cultural barriers that play a crucial role in the interiorization of a series of roles and cultural preferences. In order words, they are "the influence of socialization on the development of differential characteristics between men and women" (Ramos et al., 2003, p. 270). It refers to the identity of the feminine gender. Tomás and Guillamon (2009) identify them as socially desirable behaviors in women, related to the sense of duty, willingness to serve and lack of competitiveness or ambition to have power. Ramos et al. (2003) add a third classification to the factors or internal and external barriers related to the reproductive and family role. This is the reconciliation of work and personal/family life. De Anca and Aragón (2007) identify the internal factors as personal factors that permit a woman to evaluate the options and decisions that are going to mark her professional career.

Similar to this classification, we have identified another along similar lines created by Doubell and Stru wig (2014), which classifies personality factors, cultural context factors, organizational factors and external factors.

Since each author establishes a different classification for the determining factors, a summary table is presented below (Table 2) showing all the classifications and which makes it possible to extract a single typology that would make it possible to encompass them all.

Based on this analysis and in light of the lack of unanimity in terms of classifying the factors, it is believed that it would be interesting to contribute a typology that would allow the factors to be grouped together in the best way possible, attempting to follow the classifications studied in this regard and unify to a certain extent the different criteria described so far. 


\begin{tabular}{|c|c|c|}
\hline Author & Classification & Factors \\
\hline \multirow[t]{2}{*}{ Oakley (2000) } & Organizational & $\begin{array}{l}\text { Career development and training, promotion policies, } \\
\text { compensation policies }\end{array}$ \\
\hline & Cultural & $\begin{array}{l}\text { Male think, manager think; leadership style, gender } \\
\text { stereotype, power, contact network }\end{array}$ \\
\hline \multirow[t]{3}{*}{ Ramos, Barberá and Sarrió (2003) } & External & $\begin{array}{l}\text { Gender roles, organizational culture, contact } \\
\text { networks }\end{array}$ \\
\hline & Internal & Gender stereotypes, leadership styles, role conflicts \\
\hline & $\begin{array}{l}\text { Home and family } \\
\text { responsibilities }\end{array}$ & $\begin{array}{l}\text { Reconciliation of home and work space, assuming } \\
\text { roles as a priority duty, dual role }\end{array}$ \\
\hline \multirow[t]{2}{*}{ De Anca and Aragón (2007) } & External & $\begin{array}{l}\text { Social: gender stereotypes, lack of female role } \\
\text { models. } \\
\text { Organizational: lack of flexibility on the part of } \\
\text { companies, difficulty in reconciliation }\end{array}$ \\
\hline & Internal & Personal context, training, personal career \\
\hline \multirow[t]{2}{*}{ Agut Nieto and Martín (2007) } & External & $\begin{array}{l}\text { Gender stereotypes, labor market segregation, labor } \\
\text { discrimination of women, sexual harassment at work, } \\
\text { mobbing at work, fewer career development } \\
\text { opportunities, lack of a consolidated labor policy, } \\
\text { difficulty in sharing household and family } \\
\text { responsibilities }\end{array}$ \\
\hline & Internal & $\begin{array}{l}\text { Low self-efficacy in male matters, training in } \\
\text { feminine areas }\end{array}$ \\
\hline \multirow[t]{2}{*}{ Dezsó and Ross (2010) } & Positive & $\begin{array}{l}\text { Diversity, differences in management behavior, new } \\
\text { ideas and perspectives }\end{array}$ \\
\hline & Negative & $\begin{array}{l}\text { Lack of cohesion, different leadership styles, power } \\
\text { struggles, gender stereotypes, emergence of } \\
\text { subgroups }\end{array}$ \\
\hline \multirow[t]{3}{*}{ Mensi-Klarbach, 2014} & Social & $\begin{array}{l}\text { Gender stereotypes, vertical and horizontal } \\
\text { segregation, good management rules }\end{array}$ \\
\hline & Organizational & $\begin{array}{l}\text { Diversity, organizational culture, power relationships, } \\
\text { segregation }\end{array}$ \\
\hline & Individual & Social networks, experience, values \\
\hline \multirow[t]{4}{*}{ Doubell and Struwig (2014) } & Associated with personality & Self-efficacy, self-control, self-esteem \\
\hline & Cultural context & $\begin{array}{l}\text { Power distance, uncertainty management, } \\
\text { individualism/collectivism, masculinity/femininity }\end{array}$ \\
\hline & Organizational & $\begin{array}{l}\text { Gender stereotypes, leadership stereotypes, lack of } \\
\text { role models and mentoring, inaccessible networks, } \\
\text { inhospitable organizational culture }\end{array}$ \\
\hline & External & $\begin{array}{l}\text { Family support, professional support form } \\
\text { associations, governmental initiatives }\end{array}$ \\
\hline \multirow[t]{2}{*}{$\begin{array}{l}\text { Pletzer, Nikolova, Kedzior and } \\
\text { Voelpel (2015) }\end{array}$} & Positive & $\begin{array}{l}\text { Diversity, differences in management behavior, new } \\
\text { ideas and perspectives }\end{array}$ \\
\hline & Negative & $\begin{array}{l}\text { Lack of cohesion, different leadership styles, power } \\
\text { struggles, gender stereotypes, emergence of } \\
\text { subgroups }\end{array}$ \\
\hline \multirow[t]{2}{*}{ Moncayo Orjuela and Zuluaga (2015) } & External & $\begin{array}{l}\text { Lack of mentoring and support for women, open } \\
\text { interference with promotion by other members, } \\
\text { harassment and female work quorum, gender salary } \\
\text { differences, lack of leadership models }\end{array}$ \\
\hline & Internal & $\begin{array}{l}\text { Female self-esteem, fear of failure, lack of } \\
\text { competitiveness, misinformation on access to } \\
\text { positions in order to apply for them }\end{array}$ \\
\hline
\end{tabular}

Table 2. Summary of the classifications of the factors, according to the authors

The most contemporary approaches prefer to understand the person in relation to contextual factors. However, individual factors cannot be left out, which instead of constituting personal resources to take on obstacles, represent a barrier to access to positions of responsibility (de Anca \& Aragón, 2007). In this same sense, the classifications separate socialized and self-imposed attributes from those demanded and established by the 
context (Moncayo Orjuela \& Zuluaga, 2015). Therefore, as indicated by the literature reviews, it is necessary to distinguish among the factors that are internal or personal to oneself and factors imposed from the outside. In this sense, they can be imposed by the social context or by the organizational context.

Throughout the analysis of the classifications, a series of discrepancies is observed. First of all, the difference between internal and external factors is very slight, in some cases. While the external factors are clear, since they are beyond the scope of any organization and any personal circumstance, the internal factors are not well explained. Agut Nieto and Martín (2007) include the lack of self-efficacy and traditionally feminine training as internal factors, while Ramos et al. (2003) include gender stereotypes and leadership styles. The former alludes to factors of a more personal type, while the latter refer to more social factors. Moncayo Orjuela and Zuluaga (2015) and de Anca and Aragón (2007) incorporate personal context, lack of self-esteem and fear of failure in internal factors.

For this reason, in our classification, we felt it was necessary to eliminate the nomenclature "internal factor" per se, replacing it with "personal factor" to group the factors that depend directly on the personal and individual circumstances of each woman.

Furthermore, to group the factors referring to the social context, such as gender stereotypes, public policies and the different roles, for example, we have added the classification of "social factors."

Finally, the organizational factor is maintained, due to its importance and because all of the authors consider it; in the case of the authors who do not explicitly consider it, they include it under external factors. In our classification, it is considered a category in and of itself, due to the importance that its factors have when it comes to influencing the development of the professional career of women.

As a result, this analysis intends to organize our classification of factors according to:

1. Personal factors

2. Organizational factors

3. Social factors

\subsection{Personal factors}

Personal factors are defined as the individual factors inherent to the person him or herself.

Within this classification, we would have the factors described above: internal factors, family responsibility and training and development.

Family responsibility is an undeniable aspect in the satisfaction of the individual (León \& Chinchilla, 2004), and as such, it must be framed within a personal context. The literature studies family responsibilities from an individual perspective, depending on the woman in question, her marital status, number of children, age, family type, etc. (Zabludovsky, 2007; Cuadrado \& Morales, 2007; Sarrió, Barberá, Ramos \& Candela, 2002). These are the factors that are linked directly to the person.

In terms of training and development, these also constitute a personal factor, as the training and development each person can have are different. Traditionally, there has been discussion of the lack of training for women to occupy management positions; however, this barrier has been moving in a favorable direction (Ridgeway, 2001; Pallarès \& Martínez, 1993; de Anca \& Aragón, 2007).

The last factor that would be included in this classification is the internal factor. This refers to those factors rooted in the personal sphere, according to Moncayo Orjuela and Zuluaga (2015).We are talking about selfesteem, the fear of success, the lack of confidence and security (Oplatka, 2006). 
Generally, all these factors are included in the factor classifications within personality factors (Doubell \& Struwig, 2014) or internal factors (de Anca \& Aragón, 2007; Moncayo Orjuela \& Zuluaga, 2015; Agut Nieto \& Martín, 2007).

\subsection{Organizational factors}

Organizational factors are defined as all the factors that are determined by the organization. In this sense, the organizational factors that can be encompassed in this classification are leadership, the organizational culture, organizational support and social or work networks.

First of all, the leadership factor refers to the different leadership styles and the different qualities men and women have to lead (Eagly, 1987). In the organizational sphere, leadership is something described as masculine (O’Neil, Hopkins \& Bilimoria, 2008; Eagly, 2007). It is appropriate to include leadership within the organizational factor because this research analyzes leadership from an organizational perspective and considering the need to analyze how organizations today are characterized by typically masculine leadership styles, and the feminine style is scarcely present (Yáñez \& Godoy, 2008).

Secondly, the organizational culture, known as the values shared by all the members of the organization and with which they identify, according to Peters, Waterman and Jones (1982), is an organizational element; it depends directly on the organization, which is why it is included in the organizational factor. The organizational culture can only be understood in the context of the organization; it is something that is imposed by the organization.

Thirdly, organizational support is a factor that has been taken from the description of support. Within support, we can distinguish between organizational support and external support. When we say organizational support, we are referring to the internal support that the company gives its members, and thus it must necessarily be an organizational factor (Bilimoria \& Piderit, 2007; Ibarra, Carter \& Silva, 2010).

Finally, the social or contact network factor is all the relationships that can be established that are directly or indirectly related to work. They allow access to resources that affect a woman's progress in terms of salary, promotion, personal and professional recognition, etc. These networks also provide access to information and valuable resources for professional development. They are networks that are woven in the organizational sphere, and thus they must necessarily form part of the organizational factor (Terjesen, 2005; Dezsó \& Ross, 2012).

According to the literature, in the classifications analyzed, leadership, organizational support, social networks and organizational culture are included as organizational factors (Doubell \& Struwig, 2014; de Anca \& Aragón, 2007; Oakley, 2000; Mensi-Klarbach, 2014) or external factors (Agut Nieto \& Martin, 2007; Moncayo Orjuela \& Zuluaga, 2015; Ramos et al., 2003) by most authors. In this case, the authors who identify these factors as external factors do so because the only classifications that they identify are internal and external factors.

\subsection{Social factors}

Social factors are factors that do not depend on the personal or organizational circumstances. They are external factors (as they are referred to by many authors) that are determined by the context, circumstances, external contingencies, society, the market, the political situation, etc.

This classification includes factors of gender stereotypes, public policies and reconciliation of work and personal/family life.

On the one hand, according to Eagly (1987), gender stereotypes are the idea that men and women have about one another according to the social roles assumed by each. As social roles, they must be considered in external or social factors.

Public policies and policies regarding the reconciliation of work and personal/family life are those regulations or recommendations established by governments that are determined, in turn, by European requirements (Crehuet et al., 2016). These laws thus represent factors imposed externally, from the outside. 
According to the review of the literature, governmental initiatives are included as external factors (Doubell \& Struwig, 2014; Moncayo Orjuela \& Zuluaga, 2015; Agut Nieto \& Martín, 2007), as are gender stereotypes (Ramos et al., 2003; Moncayo Orjuela \& Zuluaga, 2015; Agut Nieto \& Martín, 2007).For Oakley (2000), gender stereotypes are included within cultural or behavioral factors, while Mensi-Klarbach (2014) includes them as a social factor. For this reason, in order to include all the classifications using the same nomenclature, the name "social factor" was chosen to encompass the theory by Oakley (2000) and by Mensi-Klarbach (2014).

Our classification is thus summarized in the following table (Table 3):

\begin{tabular}{|l|l|}
\hline \multirow{4}{*}{ Personal factors } & Family responsibility \\
\cline { 2 - 2 } & Training and development \\
\cline { 2 - 2 } Organizational factors & Internal factor \\
\hline \multirow{3}{*}{ Social factors } & Leadership \\
\cline { 2 - 2 } & Organizational culture \\
\cline { 2 - 2 } & Organizational support \\
\hline & Contact and work networks \\
\cline { 2 - 2 } & $\begin{array}{l}\text { Gender stereotypes } \\
\text { Public policies and reconciliation of work and } \\
\text { personal/family life }\end{array}$ \\
\hline
\end{tabular}

Table 3. Typology of the factors

\section{Conclusions and future lines of research}

The identification of typologies is basic to the development of theories and research in the social sciences. The importance of this work is clear, given that it is necessary to categorize and describe the classifications of the factors for better comprehension and to be able to propose solutions in the business world that would enable us to break the glass ceiling.

It is very important to establish typologies that can be empirically tested and thus offer solutions to the problems that affect women in managerial positions today.

In this work, the criteria used to classify the determining factors for the professional development of women in managerial positions have been analyzed in order to propose a common typology for all of them that can be used to condense a theory that can be extrapolated to other studies. To accomplish this, the literature has been duly reviewed and analyzed, by means of a systematic review.

The difficulty of this research is two-part. On the one hand, it was difficult to select the most appropriate terms or nomenclatures that reflect the meaning of the other names used by other authors, since each uses the names they deem appropriate. On the other hand, the search for articles that establish a classification of the factors was a very meticulous task, as most of the studies list and describe the factors one by one, without establishing any sort of order or classification.

Therefore, from a theoretical perspective, the contribution of the work can be synthesized as a typology obtained from a literature review and analysis, and thus it is generally accepted and substantiated by previous research. This typology encompasses, in the best way possible, the factors that determine the professional career of women in managerial positions.

With regard to future lines of research, another research study is underway that describes in detail each of the factors belonging to the typology proposed here. It would thus be a research project that would theoretically confirm the typology with the detailed description of each of the factors corresponding to personal, organizational and social factors. In terms of the practical implications of the work, it is essential to test this typology through an empirical analysis that would permit generalizing this typology and discussing taxonomy.

Ultimately, the main gap found throughout the literature review is focused on the lack of a classification. From the selection of 50 articles, only 9 articles present a classification. Another important gap is the lack of the use 
of a common nomenclature, since some authors, for example, use the term social and others the term external to refer to factors that do not depend on either the organization the woman belongs to or to the woman herself.

Finally, this work also has implications from a business perspective, as it can serve as a reference for business executives whose aim is to promote the role of women in positions of responsibility within organizations, which will enable them to recognize the factors that determine their development and act in their favor.

\section{Declaration of Conflicting Interests}

The author declared no potential conflicts of interest with respect to the research, authorship, and/or publication of this article.

\section{Funding}

The author received no financial support for the research, authorship, and/or publication of this article.

\section{References}

Acker, J. (2006). Inequality regimes: Gender, class, and race in organizations. Gender \& society, 20(4), 441-464. https://doi.org/10.1177/0891243206289499

Aguirre, Z., \& Martínez, M.P. (2006). Influencia de la situación laboral en el ajuste familia- trabajo. Mapfre Medicina, 17(1), 14-24. Retrieved from:

http://www.mapfre.com/fundacion/html/revistas/medicina/v17n1/pag02 02 res.html

Agut Nieto, S., \& Martín Hernández, P. (2007). Factores que dificultan el acceso de las mujeres apuestos de responsabilidad: una revisión teórica. Apuntes de Psicología, 25(2), 201-214. Retrieved from: https: $/ /$ dialnet.unirioja.es $/$ servlet $/$ articulo? codigo $=2350842 \&$ info $=$ resumen\&idioma $=$ SPA

Álvarez, A., \& Gómez, I.C. (2010). Conflicto trabajo-familia, en mujeres profesionales que trabajan en la modalidad de empleo. Pensamiento Psicológico, 9(16), 89-106. Retrieved from: http://www.redalyc.org/articulo.oa? $\underline{\mathrm{id}=80118612006}$

Belzunegui Eraso, A. (2008). Teletrabajo en España, acuerdo marco y administración pública. Revista Internacional de Organizaciones (RIO), 1, 129-148. https://doi.org/10.17345/rio1.129-148

Berkovich, M., Leimeister, J.M., \& Krcmar, H. (2011). Requirements engineering for product service systems. Business \& Information Systems Engineering, 3(6), 369-380. https://doi.org/10.1007/s12599-011-0192-2

Bilimoria, D., \& Piderit, S.K. (2007). Handbook on women in business and management. Cheltenham: Edward Elgar. https://doi.org/10.4337/9781847204134

Bozart, C., \& McDermott, C. (1998). Configurations in manufacturing strategy: A review and directions for future research. Journal of Operations Management, 16(4), 427-439. https://doi.org/10.1016/S0272-6963(98)00022-9

Cánovas, A., Aragón, J., \& Rocha, F. (2005). Las políticas de conciliación de la vida familiar y laboral en las Comunidades Autónomas. Cuadernos de Relaciones Laborales, 23(1), 73-93.

Cousté, N.L. (1997). La tipología de estrategias de Miles y Snow: Un estudio aplicando una escala multiítem 1. Revista Europea de Dirección y Economia de la Empresa, 6(2), 33-44.

Cuadrado, I. (2003). ¿Emplean hombres y mujeres diferentes estilos de liderazgo? Análisis de la influencia de los estilos de liderazgo a los puestos de dirección. Revista de Psicología Social, 18, 283-307.

https://doi.org/10.1174/021347403322470864

Cuadrado, I., \& Morales, J. (2007). Algunas claves sobre el techo de cristal en las organizaciones. Revista de Psicologia del Trabajo y de las Organizaciones, 23, 183-202.

De Anca, C., \& Aragón, S. (2007). La mujer directiva en España: Catalizadores e inhibidores en las decisiones de trayectoria profesional. Academia, Revista Latinoamericana de Administración, (18), 45-63. 
Dess, G.G., Newport, S., \& Rasheed, A.M. (1993). Configuration research in strategic management: Key issues and suggestions. Journal of Management, 19(4), 775-795. https://doi.org/10.1177/014920639301900403

Dezsó, C.L., \& Gaddis Ross, D. (2012). Does Female Representation in Top Management Improve Firm Performance? A Panel Data Investigation. Strategic Management Journal, 33, 1072-1089.

https://doi.org/10.1002/smj.1955

Directiva del Consejo Europeo de 9 de febrero de 1976 relativa a la aplicación del principio de igualdad de trato entre hombres y mujeres en lo que se refiere al acceso al empleo, a la formación y a la promoción profesionales, y a las condiciones de trabajo (76/207/CEE).

Directiva del Consejo Europeo de 10 de febrero de 1975 relativa a la aproximación de las legislaciones de los Estados Miembros que se refieren a la aplicación del principio de igualdad de retribución entre los trabajadores masculinos y femeninos (75/117/CEE).

Doty, D., \& Glick, W. (1994). Typologies as a Unique Form of Theory Building: Toward Improved Understanding and Modeling. The Academy of Management Review, 19(2), 230-251. Retrieved from: http://www.jstor.org/stable/258704

Doty, D.H., Glick, W.H., \& Huber, G.P. (1993). Fit, equifinality, and organizational effectiveness: A test of two configurational theories. Academy of Management journal, 36(6), 1196-1250. https://doi.org/10.2307/256810

Doubell, M., \& Struwig, M. (2014). Perceptions of factors influencing the career success of professional and business women in South Africa. South African Journal of Economic and Management Sciences, 17(5), 531-543. https://doi.org/10.4102/sajems.v17i5.514

Durán, M.A. (ed.) (1997). Las bases sociales de la economía española. Valencia: Universidad de Valencia.

Eagly, A.H. (1987). Reporting sex differences.

Eagly, A.H. (2007). Female leadership advantage and disadvantage: Resolving the contradictions. Psychology of Women Quarterly, 31, 1-12. https://doi.org/10.1111/j.1471-6402.2007.00326.x

Eagly, A., \& Carli, L. (2007). Women and the Labyrinth of Leadership. Harvard Business Review, 85, 63-71.

Festing, M., Knappert, L., \& Kornau, A. (2015). Gender-specific preferences in global performance management: an empirical study of male and female managers in a multinational context. Human Resource Management, 54(1), 55-79. https://doi.org/10.1002/hrm.21609

Geraldi, J., Maylor, H., \& Williams, T. (2011). Now, let's make it really complex (complicated) A systematic review of the complexities of projects. International Journal of Operations \& Production Management, 31(9), 966-990. https://doi.org/10.1108/01443571111165848

Guirao, C. (2011). Nuevas formas de relación trabajo productivo y sociedad: La conciliación de la vida familiar y laboral. Prisma Social, 6(Junio, 2011), 1-27. Retrieved from:

http://www.isdfundacion.org/publicaciones/revista/numeros/6/secciones/tematica/05-nuevas-formas-relaciontrabajo-productivo.html

Hafsteinsdóttir, T.B., van der Zwaag, A.M., \& Schuurmans, M.J. (2017). Leadership mentoring in nursing research, career development and scholarly productivity: A systematic review. International Journal of Nursing Studies, 75, 21-34. https://doi.org/10.1016/j.ijnurstu.2017.07.004

Hambrick, D., \& Mason, P. (1984). Upper Echelons: The Organization as a Reflection of Its Top Managers. The Academy of Management Review, 9(2), 193-206. Retrieved from:http://www.jstor.org/stable/258434

Hancock, M.G., \& Hums, M.A. (2016). A "leaky pipeline"?: Factors affecting the career development of seniorlevel female administrators in NCAA Division I athletic departments. Sport Management Review, 19(2), 198-210. https://doi.org/10.1016/j.smr.2015.04.004 
Hawley, E., Torres, D., \& Rasheed, S. (1998). Assessing barriers to women's career adjustment. Journal of Career Assessment, 6(4), 449-479. https://doi.org/10.1177/106907279800600406

Hopkins, M., \& Bilimoria, D. (2008). Social and emotional competencies predicting success for male and female executives. Journal of Management Development, 27, 13- 35. https://doi.org/10.1108/02621710810840749

Ibarra, H., Carter, N.M. \& Silva, C. (2010). Why men still get more promotions than women. Instituto de la mujer. Estadísticas 2005 y 2006. Retrieved from: http://www.mtas.es/mujer/mujeres/cifras/empleo/situacion laboral.htm

Kotha, S., \& Vadlamani, B. (1995). Assessing Generic Strategies: An Empirical Investigation of Two Competing Typologies in Discrete Manufacturing Industries. Strategic Management Journal, 16(1), 75-83. https://doi.org/10.1002/smj.4250160108

Kumra, S. (2010). Exploring Career "choices" of work-centred women in a professional service firm. Gender in Management: An International Journal, 25 (3), 227-243. https://doi.org/10.1108/17542411011036428

León, C., \& Chinchilla, N. (2004). Directivas en la empresa: Criterios de decisión y valores femeninos en la empresa. Documento de trabajo del IESE.

Lucia-Casademunt, A.M., Ariza-Montes, J.A., \& Morales-Gutiérrez, A. C. (2013). La implicación emocional de los empleados de banca en Europa. Universia Business Review, (38), 32-49.

Marín-García, Juan A., \& Martínez Tomás, J. (2016). Deconstructing AMO framework: A systematic review. Intangible Capital, 12(4), 1040-1087. https://doi.org/10.3926/ic.838

Martínez-Pérez, M.D., \& Osca, A. (2004). El éxito profesional desde una perspectiva de género: Propuesta de un modelo. Revista de Psicología General y Aplicada, 57(2), 193-208. Número monográfico "La psicología y el acceso de la mujer a la función directiva" (Coordinadores: J. F. Morales e I. Cuadrado).

Mensi-Klarbach, H. (2014). Gender in top management research: Towards a comprehensive research framework. Management Research Review, 37(6), 538-552. https://doi.org/10.1108/MRR-03-2013-0066

Meyer, A.D., Tsui, A., \& Hinings, C. (1993). Guest Co-editors' Introduction: Configurations Approaches to Organisational Analysis. Academy of Management Journal, 36(6), 1175-1195. https://doi.org/10.2307/256809

Miller, D. (1996). Configurations Revised. Strategic Management Journal,17, 505-512. https://doi.org/10.1002/ (SICI)1097-0266(199607)17:7<505::AID-SMJ852>3.0.CO;2-I

Moncayo Orjuela, B.C., \& Zuluaga, D. (2015). Liderazgo y género: Barreras de mujeres directivas en la academia. Pensamiento \& Gestión, (39), 142-177.

O'Neil, D.A., Hopkins, M.M., \& Bilimoria, D. (2008), Women's careers at the start of the twenty-first century: Patterns and paradoxes. Journal of Business Ethics, 80(4), 727-743. https://doi.org/10.1007/s10551-007-9465-6

Oakley, J.G. (2000). Gender-based Senior Barriers to Management Positions: Understanding Scarcity of Female CEOs. Slideheaven, 27(4), 321-334.

Oplatka, I. (2006). Women in educational administration within developing countries: Towards a new international research agenda. Journal of Educational Administration, 44(6), 604-624. https://doi.org/10.1108/09578230610704819

Pallarès, S., \& Martínez, M. (1993). Imágenes de la Dirección: Metáforas de la función directiva desde la propia dirección. Revista de Psicología, 4, 27.

Pateli, A.G., \& Giaglis, G.M. (2004). Framework for analyzing eBusiness. European Journal of Information Systems, 13, 302-314. https://doi.org/10.1057/palgrave.ejis.3000513

Peters, T.J., Waterman, R.H., \& Jones, I. (1982). In search of excellence: Lessons from America's best-run companies. New York: Harper \& Row. 
Pletzer, J.L., Nikolova, R., Kedzior, K.K., \& Voelpel, S.C. (2015). Does Gender Matter? Female Representation on Corporate Boards and Firm Financial Performance - A Meta-Analysis. Plos One, 10(6), e0130005. https://doi.org/10.1371/journal.pone.0130005

Ramos López, M.A., Barbera, E., \& Sarrió Catalá, M. (2003). Mujeres directivas, espacio de poder y relaciones de género. Anuario de Psicologia, 34, 267-278.

Richardson, P.R., Taylor, A.J., \& Gordon, J.R.M. (1985), A Strategic Approach to Evaluating Manufacturing Performance. Interfaces, 15(6), 15-27. https://doi.org/10.1287/inte.15.6.15

Ridgeway, C.L. (2001). Gender, status, and leadership. Journal of Social Issues, 57(4), 637-655. https://doi.org/10.1111/0022-4537.00233

Rincón, V., González, M., \& Barrero, K. (2017). Women and leadership: Gender barriers to senior management positions. Intangible Capital, 13(2), 319-386. https://doi.org/10.3926/ic.889

Sabater Fernández, M.C. (2014). La interacción trabajo-familia. La mujer y la dificultad de la conciliación laboral. Lan harremanak: Revista de relaciones laborales, 30(30), 163-198. Retrieved from: http://dialnet.unirioja.es/servlet/articulo? $\operatorname{codigo}=5029809 \&$ info $=$ resumen\&idioma $=\mathrm{ENG}$

Sarrió, M., Barberá, E., Ramos, A., \& Candela, C. (2002). El techo de cristal en la promoción profesional de las mujeres. Revista de Psicología Social, 17 (2), 167-182. https://doi.org/10.1174/021347402320007582

Selva, C., Sahagún, M.A., \& Pallarès, S. (2011). Estudios sobre trayectoria profesional y acceso de la mujer a cargos directivos: Un análisis bibliométrico. Revista de Psicología del Trabajo y de las Organizaciones, 27(3), 227-242. https://doi.org/10.5093/tr2011v27n3a6

Sullivan, S.E., \& Mainiero, L. (2008). Using the kaleidoscope career model to understand the changing patterns of women's careers: Designing HRD programs that attract and retain women. Advances in Developing Human Resources, 10(1), 32-49. https://doi.org/10.1177/1523422307310110

Swanson, J., \& Witke, M. (1997). Theory into practice in career assessment for women: Assessment and interventions regarding perceived barriers. Journal of Career Assessment, 5, 443-462.

https://doi.org/10.1177/106907279700500405

Terjesen, S. (2005). Senior women managers' transition to entrepreneurship Leveraging embedded career capital. Career Development International, 10, 246-259. https://doi.org/10.1108/13620430510598355

Terjesen, S., \& Singh, V. (2008). Female presence on corporate boards: A multi-country study of environmental context. Journal of Business Ethics, (83), 55-63. https://doi.org/10.1007/s10551-007-9656-1

Tomás, M., \& Guillamon, C. (2009). Las barreras y los obstáculos en el acceso de las profesoras universitarias a los cargos de gestión académica. Revista de Educación, 350, 253- 275.

Webster, J., \& Watson, R.T. (2002). Analyzing the past to prepare for the future: Writing a literature review. MIS quarterly, 26(2), 13-23.

Wirth, L. (2001). Breaking through the glass-ceiling: women in management. Geneva: International Labour Office.

Yáñez, S., \& Godoy, L. (2008). Effects of gender images and stereotypes on female E\&T research careers in higher education in Chile. En A.S. Godfroy-Genin (Ed.), Women in engineering and technology research. Proceedings of the PROMETEA Conference. 26-27 October 2007, Paris. Zürich: Lit Verlag.

Zabludovsky, G. (2007). México: Mujeres en cargos de dirección del sector privado. Academia. Revista Latinoamericana de Administración, 38, 9-26. 


\section{Versión en español}

Título: Factores determinantes de la carrera profesional de la mujer directiva: Propuesta de una tipología

\section{Resumen}

Objeto: El objetivo de este paper es identificar una tipología de los factores que determinan la carrera profesional de la mujer directiva, en base a las distintas aportaciones que aparecen en la literatura.

Diseño/metodología/enfoque: Se ha llevado a cabo una revisión sistemática de la literatura a través de las búsquedas en el portal Google Académico y de las bases de datos ABI, SCOPUS y WOS que permiten el análisis de múltiples artículos.

Aportaciones y resultados: La carrera profesional de la mujer directiva viene determinada por una serie de factores que motivan o limitan su desarrollo. Estos factores son comúnmente enumerados y descritos en la literatura especializada. Sin embargo, no existe una clasificación de factores que sea generalmente aceptada. Por ello, como resultados de este trabajo se propone una tipología que permite clasificar los factores determinantes de la carrera profesional de la mujer directiva.

Implicaciones prácticas: Este trabajo tiene importantes implicaciones futuras para investigadores que pretendan contrastar de forma empírica la clasificación propuesta y analizar en profundidad los factores, así como para directivos empresariales cuyo objetivo sea fomentar el papel de la mujer en puestos de responsabilidad dentro de las organizaciones.

Originalidad / Valor Añadido: Este paper destaca por la identificación de tipologías que son necesarias para el desarrollo de teorías y de investigación en las ciencias sociales. Es importante categorizar y describir las clasificaciones de los factores para poder comprenderlos mejor, para poder extrapolar una teoría común para otras investigaciones y para proponer soluciones en el ámbito empresarial que permitan romper con el techo de cristal.

Palabras Clave: Carrera directiva, Mujer directiva, Liderazgo, Factores determinantes, Tipología

Códigos JEL:J16, J24, J71, M12

\section{Antecedentes}

Tradicionalmente, la relación laboral se basaba en el padre, cabeza de familia, que trabajaba para proveer la subsistencia familiar mientras que la mujer era la encargada del hogar y del cuidado de menores y dependientes. Durante los últimos tiempos, han tenido lugar numerosos cambios a nivel económico, social, político y tecnológico que han generado una nueva relación trabajo-familia (Álvarez \& Gómez, 2010). Este nuevo binomio, trabajo-familia, hace referencia a una nueva relación basada en una doble responsabilidad que tienen tanto hombres como mujeres de asumir tareas en el ámbito laboral y en el ámbito de la familia.

Una de las principales manifestaciones de este binomio ha sido la incorporación de la mujer al mercado laboral. Este cambio supone una dinámica imparable por la progresiva igualdad entre hombres y mujeres (Sabater, 2014). El resultado de este binomio es un arma de doble filo pues tiene un sentido positivo y un sentido negativo.

El hecho de que la mujer se incorpore al mundo laboral se considera positivo porque potencia su desarrollo personal y profesional, añade más talento a las organizaciones y contribuye al bienestar económico y social ya que aumenta la población activa, las familias ingresan más dinero por un nuevo trabajo y por consiguiente, con mayor poder adquisitivo el consumo aumenta (Álvarez \& Gómez, 2010). En cuanto al aspecto negativo, se puede añadir que ante la dificultad de llevar la doble responsabilidad de trabajo y familia, lejos de procurar la igualdad, 
hombres y mujeres se ven sometidos a la institucionalización de la doble jornada, laboral y doméstica (Aguirre \& Martínez, 2006).

Desde la investigación se ha estudiado la repercusión de la incorporación de la mujer al mundo laboral por ser éste el colectivo más afectado por el binomio trabajo-familia, desde distintos ámbitos de la vida. En primer lugar, desde la dimensión social y educativa, el nivel educativo de la mujer ha ido en aumento, así como la necesidad de verse involucrada en el mundo empresarial ya sea por satisfacción y desarrollo personal o por la necesidad de obtener un doble ingreso para el mantenimiento del hogar (Sabater, 2014). La sociedad cada vez está más concienciada de la necesaria colaboración del varón en las tareas domésticas en favor de este binomio.

En según lugar, desde la dimensión económica y organizativa, Aguirre y Martínez (2006) sostienen que se están tomando medidas para favorecer la inserción de la mujer al mundo laboral, como son el aumento de jornada en los centros escolares, el incremento de actividades extraescolares o de guarderías para poder facilitar y ajustar el horario en mayor medida al horario empresarial que asumen las mujeres. Sin embargo, otras investigaciones detectan cierta rigidez en la estructura organizativa empresarial que obliga, en ocasiones, a renunciar a uno u otro eje del binomio según la disponibilidad temporal y/o económica de las familias (Durán, 1997).

En tercer lugar, desde el ámbito de género, es importante no olvidar los estereotipos que asignan a los hombres los roles de producción y confinan a la mujer en el espacio de los cuidados y tareas domésticas (Durán, 1997). No obstante, son numerosas las legislaciones que prohíben la discriminación. La Carta de Derechos Fundamentales de la Unión Europea, reconoce en sus artículos 20 y 21 el principio de igualdad ante la ley y la no discriminación por razón de sexo. Por su parte, en Directivas Europeas se ha destacado la necesidad de aproximación de las legislaciones de los Estados Miembros a la aplicación del principio de igualdad tanto en relación con la retribución entre trabajadores hombres y mujeres, así como para el acceso al empleo, formación y condiciones de trabajo (Directiva 75/117, 1975; Directiva 76/207, 1976). A pesar de todos los esfuerzos legales en este sentido, este cliché o estereotipo va a marcar el desarrollo de la carrera profesional de la mujer ya que es precisamente la diferencia de género la que determina la desigualdad económica y profesional entre hombres y mujeres (Wirth, 2001). Esto hace que muchas mujeres terminen renunciando a su proyección profesional o a su desarrollo familiar. Este último caso, repercute directamente en un claro descenso en la tasa de natalidad tal y como demuestran los datos del INE, en 2015, cuando el número medio de hijos por mujer en España se situaba en 1.33 (INE, 2016).

Por último, desde los poderes públicos se observa un esfuerzo por desarrollar políticas públicas que ayuden a las familias al desarrollo profesional de la mujer (Guirao, 2011). A nivel laboral se han producido cambios que han permitido el aumento de la presencia de las mujeres en el mundo profesional. Por ejemplo, se regulan los permisos relacionados con el cuidado de familiares, se introduce el teletrabajo permitiendo una mayor flexibilidad de tiempos y lugares de trabajo, se fomenta el autoempleo con incentivos fiscales, se fomenta la contratación con bonificaciones de la Seguridad Social y distintos tipos de contratación (como es la modalidad de a tiempo parcial), entre otras medidas (Cánovas, Aragón \& Rocha, 2005; Belzunegui, 2008; Martínez \& Osca, 2004). Aunque todo esto no resulta tan evidente para cargos directivos en grandes empresas, dado que los esfuerzos políticos se concentran en los niveles bajos de la pirámide organizativa y escasean las medidas para facilitar el acceso a cargos directivos y para fomentar la conciliación en niveles directivos.

Muchos son los estudios que estudian los factores de forma genérica y que insisten entre la correlación de la producción académica y la práctica institucional (Hopkins \& Bilimoria, 2008; Sullivan \& Mainiero, 2008). Es decir, muchos estudios reflejan las limitaciones que se encuentra la mujer durante el desarrollo de su carrera profesional (Rincón, González \& Barrero, 2017) y por consiguiente reclaman la necesidad de que los gobiernos tomen partido y establezcan medidas y soluciones institucionales (Lucia-Casademunt, Ariza-Montes \& Morales Gutiérrez, 2013; Ramos, Barberá \& Sarrió, 2003; Moncayo Orjuela \& Zuluaga, 2015). Sin embargo, pese a la gran producción académica en relación a las barreras y facilitadores de la trayectoria profesional de la mujer, son pocas las producciones de artículos que recogen una clasificación de los factores que permita agruparlos de una forma unánime y coherente. Si bien es muy importante saber cuáles son los factores que afectan directamente a la mujer 
en su desarrollo profesional, igual de importante es agrupar los factores en tipologías con ánimo de comprender mejor cada uno de ellos de forma individual y enmarcarlos en un contexto y circunstancias determinadas.

Por tanto, se hace necesario clasificar esos factores que marcan el desarrollo profesional de las mujeres directivas para entenderlos mejor, ir a la causa u origen de cada uno de ellos y así poder presentar soluciones y medidas favorecedoras para las mujeres. Por ello, el objetivo de este trabajo es:

- proponer una clasificación de los factores que aúne los criterios de los autores que establecen clasificaciones

- establecer un modelo de tipología común a todos y que pueda ser contrastado empíricamente en futuros trabajos de investigación.

Este trabajo se estructura de la siguiente manera: en primer lugar, se describe la metodología empleada, en segundo lugar,se describen los resultados y por último las conclusiones y líneas futuras.

\section{Metodología}

Una tipología se define conceptualmente como "tipos ideales" que presentan una combinación de atributos comunes (Doty \& Glick, 1994). Dess, Newport y Rasheed (1993) consideran que las tipologías deben referirse solo a un sistema de clasificación conceptual desde un punto de vista teórico. Para ello, el investigador traza un marco conceptual desarrollado "a priori” y una vez diseñado se contrastaría de forma empírica (Cousté, 1997). Las tipologías son un mecanismo que se emplea para describir estructuras, estrategias, características y entornos o contextos. Cualquier tipología se caracteriza por las siguientes claves: (Bozart and McDermott, 1998):

- Las tipologías deben ofrecer una teoría que pueda ser extrapolable y aplicable de forma individual (Doty and Glick, 1994).

- Cualquier teoría debe especificar las dimensiones individuales que la constituyen (Miller, 1996).

- Las tipologías son consideradas afirmaciones teóricas y desde ellas se pueden diseñar hipótesis que puedan ser empíricamente contrastadas (Doty, Glick \& Huber, 1993; Richardson, Taylor \& Gordon, 1985; Kotha \& Vadlamani, 1995).

Las tipologías, en definitiva son meramente conceptuales, pero no pueden ser totalmente desarrolladas hasta que no sean validadas desde un punto de vista empírico (Meyer, Tsui \& Hinings, 1993). Por tanto, en esta investigación lo que se pretende es definir una clasificación ideal de los factores que determinan el desarrollo profesional de la mujer directiva. Ante la complejidad de su validación empírica también hay que señalar que siempre hay un residuo a considerar. Esto es una opción de que esta tipología no pueda encajar para algunos casos (Cousté, 1997).

Para el análisis de los factores se ha empleado una metodología de revisión sistemática de la literatura que cada vez va adquiriendo mayor importancia en los estudios de ciencias sociales (Webster \& Watson, 2002; Geraldi, Maylor \& Williams, 2011).

\subsection{Fases de la metodología de revisión sistemática de la literatura}

La metodología empleada para esta revisión sistemática de la literatura se ha divido en dos fases. Una primera fase de identificación y selección de los estudios relevantes y una segunda fase de análisis de dichos estudios (Pateli \& Giaglis, 2004).

\subsubsection{Fase de identificación y selección}

Para la búsqueda individual de los artículos se realizaron las búsquedas, filtrando por título de documento y abstract, en el portal Google Académico que cubre la mayor parte de revistas y publicaciones electrónicas (Berkovich, Leimeister \& Krcmar, 2011) así como en la base de datos ABI, SCOPUS y WOS. Dichas búsquedas 
fueron realizadas durante los meses de enero a octubre del año 2017. El periodo de análisis es de 2000 a octubre 2017. Este periodo se debe a que según Selva, Sahagún y Pallarès (2011) en el análisis bibliométrico sobre la trayectoria profesional y acceso de la mujer a cargos directivos, desde inicios de siglo "el tema cobra mayor interés” y se acumulan cerca del 78\% de los artículos publicados en esta materia a partir del año 2000.

En la búsqueda se introdujeron las siguientes expresiones o combinaciones de palabras clave dado que son las que más se repiten en los estudios científicos de la mujer directiva: executive woman factors, directive woman, factors, gender career, woman career development, woman entrepreneurship, diversity in board of directors, women management, women leadership. Estos términos se buscaron tanto en el título del documento como en el abstract.

Para explicar en mayor medida esta búsqueda se considera relevante describir los criterios de inclusión y exclusión (Marín-García \& Martínez-Tomás, 2016). Por tanto, ente los criterios de inclusión se destacan papers publicados en bases de datos ABI, SCOPUS, Web of Science y Google Scholar. Además, se incluyen los artículos publicados entre 2000 y 2017 escritos tanto en español como en inglés. Además, se han considerado aquellos artículos que contienen en su título o en el abstract las expresiones o combinaciones de palabras clave arriba citadas. Por su parte, entre los criterios de exclusión se descartan los papers publicados con anterioridad al año 2000 y en idioma que no sea español o inglés. Además, se han descartado artículos que no contienen ningún tipo de clasificación de los factores. Son muchos los artículos que describen a la perfección los factores que determinan la carrera profesional de la mujer directiva (Kumra, 2010; Festing, Knappert \& Kornau, 2015; Hopkins \& Bilimoria, 2008; Eagly \& Carli, 2007; Cuadrado, 2003; Hafsteinsdóttir, Van del Zwaag \& Schuurmans, 2017; Hancock \& Hums, 2016; Terjesen \& Singh, 2008). No obstante, se ha considerado importante, para la elaboración de la tipología, incluir exclusivamente los artículos que presentan algún tipo de clasificación.

En la fase de selección,el criterio seguido para la elección de los artículos fue por un lado que el contenido del abstract estuviera relacionado directamente con el tema de investigación, factores determinantes de la carrera profesional de la mujer directiva, y por otro lado, la frecuencia de citas de cada uno de los artículos.Como resultado se obtuvo:

- Un conjunto de artículos que analizaban los factores que motivan y limitan la carrera profesional de la mujer. Estos artículos son los que se han tenido en cuenta para este paper.(50 artículos de esta categoría).

- Un conjunto de artículos de experiencia que la mujer tiene de los distintos momentos de su trayectoria profesional. (26 artículos de esta categoría)

- Un conjunto de artículos que estudian a la mujer de forma sectorial: ya sean artículos que atienden a un sector específico, a un país específico, a una posición determinada etc.(12 artículos de esta categoría).

- Un conjunto de artículos que analizan el éxito profesional que tienen las mujeres en términos cuantitativos o de resultados.(6 artículos de esta categoría).

- Un conjunto de artículos que presentan soluciones institucionales para impulsar la presencia de mujeres en puestos directivos y favorecer la diversidad. (6 artículos de esta categoría).

En esta investigación, nos hemos centrado en el primer conjunto de artículos: artículos que analizan los factores en términos generales. En este proceso el número de artículos encontrados pertenecientes a esta categoría es de 50.

\subsubsection{Fase de análisis}

En la fase de análisis, después de haber leído cuidadosamente los 50 artículos, se han analizado con detenimiento 24 artículos por ser los que analizan con mayor profundidad el tema de investigación objeto de estudio, por ser los más citados y los que cubren más extensamente los objetivos de este trabajo (TABLA 1). 


\begin{tabular}{|l|r|r|}
\hline Categoría & Número de artículos & \multicolumn{1}{|c|}{ Frecuencia } \\
\hline $\begin{array}{l}\text { Investigaciones teóricas o de } \\
\text { revisión }\end{array}$ & 11 & $45.8 \%$ \\
\hline Investigaciones cuantitativas & 13 & $54.2 \%$ \\
\hline Total & 24 & $100 \%$ \\
\hline
\end{tabular}

Tabla 1. Análisis de artículo

Los 24 artículos analizados corresponden a los años 2000-2015. De los 24 artículos un 45.8\% son investigaciones teóricas o de revisión (11 artículos) y 54.2\% son investigaciones cuantitativas (13 artículos). Además, de estos 24 artículos sólo un 37.5\% son artículos que proponen clasificaciones a estos factores (9 artículos). Se pueden encontrar estos artículos en las revistas del área de management (por ejemplo en Strategic Management Journal, Management Research Review, South AfricanJournal of Economic and Management Sciences, Academia Revista Latinoamericana de Administración, Pensamiento y Gestión) o en revistas del área de la psicología (Journal of Business Ethics, Apuntes de Psicología, Anuario de Psicología).

Para el análisis de los 9 artículos finales, se ha realizado una tabla con las siguientes categorías para un mejor estudio de los mismos (Marín-García \& Martínez-Tomás, 2016):

- Artículo: especificando el título del artículo, el año y el autor. Ejemplo: Mensi-Klarbach (2014). Gender in top management research. Towards a comprehensive research framework.

- Objetivo: descripción breve del objeto de estudio. Ejemplo: ofrecer una aproximación de las diferencias de género en los consejos de administración.

- Estudio: indicar el tipo de estudio. Ejemplo: estudio conceptual sobre el rol de género en los consejos de administración.

- $\quad$ Periodo de análisis: 1984-2014

- Hipótesis: hipótesis que presentan relación entre el género y el impacto que tiene sobre la posición directiva. Ejemplo: Hipótesis 1: los altos directivos tienen un impacto directo sobre los resultados de la organización; Hipótesis 2: las diferencias entre hombres y mujeres afectan directamente al trabajo en la alta dirección.

- Resultados: este apartado se utilizará para verificar si las hipótesis propuestas han sido o no contrastadas. Ejemplo: debido a las diferencias entre hombres y mujeres se procede a una clasificación de factores: sociales, organizativos e individuales para entender el impacto del género en las posiciones de alta dirección.

\section{Resultados. Propuesta de tipología}

En las investigaciones que se han revisado, el análisis de los factores se realiza de múltiples formas. La mayoría de los estudios que identifica clasificaciones son de revisión. Es decir, artículos cuyo contenido no es empírico y simplemente se limita a hacer una revisión o una reflexión disciplinaria que busca examinar la bibliografía publicada (Selva et al., 2011).

En estos artículos analizados, los factores se clasifican de forma muy diversa. Existen varias clasificaciones. Por un lado se habla de factores de contexto social, contexto organizacional y contexto individual (Mensi-Klarbach, 2014). Según el contexto social, las organizaciones operan en un environment determinado con unas circunstancias sociales determinadas. Por ejemplo, en el caso que puntualiza Mensi-Klarbach (2014) se hace especial referencia a la segregación vertical y horizontal como elemento social que determina la carrera profesional de las mujeres. En cuanto al contexto organizativo, Acker (2006) establece que el comportamiento de las organizaciones y especialmente de los Consejos de Administración debe tener en cuenta la identidad de igualdad de género que está presente en la sociedad y por tanto también en las organizaciones hoy en día. Por último, el contexto 
individual se entiende como las características individuales de las personas que deben considerarse ya que tiene un impacto directo en la contribución de las mujeres directivas a las organizaciones (Hambrick \& Mason, 1984).

Otra clasificación de factores sería la de factores positivos y factores negativos (Pletzer, Nikolova, Kedzior \& Voelpel, 2015; Dezsó y Ross, 2012). Esta clasificación resalta el impacto positivo o negativo sobre los resultados de la empresa que tiene la presencia de las mujeres en la alta dirección.

También se habla de otra tipología de factores. Los factores corporate u organizativos y de factores culturales y de comportamiento según Oakley (2000). Los factores organizativos son aquellos que afectan directamente a la hora de reclutar, seleccionar, retener y promocionar a las mujeres. Los factores culturales y de comportamiento son factores sociales y de género basados más en estereotipos, poder, estilo de liderazgo, más que en las políticas organizativas en cuestión.

No obstante, son mayoría, generalmente, los autores que diferencian, entre barreras internas y externas (Moncayo Orjuela \& Zuluaga, 2015; Hawley, Torres \& Rasheed, 1998; Swanson \& Witke, 1997; Ramos et al., 2003; de Anca \& Aragón, 2007; Agut Nieto \& Martín, 2007). En primer lugar, se entienden por barreras externas todas aquellas de componente sociodemográfico y contextuales que establecen la cultura organizativa y las diferencias genéricas de los estilos de liderazgo, de los estereotipos de género. Por su parte, de Anca y Aragón (2007) explican los factores externos como barreras sociales basadas en estereotipos como barreras organizacionales basadas en la cultura e identidad organizativa. En segundo lugar, se entienden por barreras internas todas aquellas barreras de tipo cultural que juegan un rol primordial en la interiorización de una serie de papeles y preferencias culturales. Es decir, "la influencia de la socialización en el desarrollo de características diferenciales entre hombres y mujeres" (Ramos et al.,, 2003, p. 270). Se refiere a la identidad de género femenino. Tomás y Guillamon (2009) las identifican como comportamientos socialmente deseables en la mujer, afines con el sentido del deber, la voluntad de servicio y la falta de competitividad o ambición para con el poder. Ramos et al. (2003) añaden a los factores o barreras internas y externas una tercera clasificación basada en el rol reproductivo y familiar. Esto es la compatibilización entre la vida laboral y la personal/familiar. De Anca y Aragón (2007) identifican los factores internos como factores personales que permiten a la mujer valorar las opciones y decisiones que van a marcar su carrera profesional.

Próxima a esta clasificación, destacamos otra en línea similar realizada por Doubell y Struwig (2014), por la que se clasifican los factores de personalidad, factores de contexto cultural, factores organizativos y factores externos.

A continuación, como cada autor establece una clasificación diferente para los factores determinantes, se realiza una tabla resumen (Tabla 2) que recoge todas las clasificaciones y que permite extraer una única tipología que permita englobar todas ellas.

En base a este análisis y a la falta de unanimidad a la hora de clasificar los factores, se considera interesante aportar una tipología que permita agrupar los factores de la mejor forma posible intentando respetar las clasificaciones estudiadas al respecto y unificar en cierto modo los distintos criterios descritos hasta ahora.

Las aproximaciones más contemporáneas prefieren entender a la persona en relación con los factores contextuales. No obstante, no se puede dejar de hablar de los factores individuales los cuales en vez de constituir recursos personales para afrontar los obstáculos suponen una barrera al acceso a puestos de responsabilidad (de Anca \& Aragón, 2007). En este mismo sentido, las clasificaciones separan atributos socializados y autoimpuestos de aquellos exigidos y establecidos por el contexto (Moncayo Orjuela \& Zuluaga, 2015). Por tanto, y tal y como apuntan las revisiones de literatura, es necesario distinguir entre factores que son internos o personales a una misma y factores impuestos desde fuera. En este sentido pueden ser impuestos por el contexto social o por el contexto organizativo. 


\begin{tabular}{|c|c|c|}
\hline Autor & Clasificación & Factores \\
\hline \multirow[t]{2}{*}{ Oakley (2000) } & Organizativos & $\begin{array}{l}\text { Desarrollo de carrera y formación, políticas de } \\
\text { promoción, políticas de compensación. }\end{array}$ \\
\hline & Culturales & $\begin{array}{l}\text { Thinkmale thinkmanager, estilo de liderazgo, estereotipo } \\
\text { de género, poder, redes de contactos. }\end{array}$ \\
\hline \multirow[t]{3}{*}{ Ramos, Barberá y Sarrió (2003) } & Externas & $\begin{array}{l}\text { Roles de género, cultura organizacional, redes de } \\
\text { contacto. }\end{array}$ \\
\hline & Internas & $\begin{array}{l}\text { Estereotipos de género, estilos de liderazgo, } \\
\text { conflictos de rol. }\end{array}$ \\
\hline & $\begin{array}{l}\text { Responsabilidades } \\
\text { domésticas y familiares }\end{array}$ & $\begin{array}{l}\text { Compatibilización del espacio doméstico y laboral, } \\
\text { asunción de roles como deber prioritario, doble rol. }\end{array}$ \\
\hline \multirow[t]{2}{*}{ De Anca y Aragón (2007) } & Externas & $\begin{array}{l}\text { Sociales: estereotipos de género, falta de modelos } \\
\text { femeninos. } \\
\text { Organizacionales: falta de flexibilidad de las } \\
\text { empresas, dificultad de conciliación. }\end{array}$ \\
\hline & Internas & Contexto personal, formación, trayectoria personal. \\
\hline \multirow[t]{2}{*}{ Agut Nieto y Martín (2007) } & Externos & $\begin{array}{l}\text { Estereotipos de género, segregación del mercado de } \\
\text { trabajo, discriminación laboral d las mujeres, acoso } \\
\text { sexual en el trabajo, acoso psicológico en el trabajo, } \\
\text { menores oportunidades de desarrollo de carrera, } \\
\text { ausencia de política laboral consolidada, dificultad de } \\
\text { compartir responsabilidades domésticas y familiares. }\end{array}$ \\
\hline & Internos & $\begin{array}{l}\text { Baja autoeficacia en cuestiones masculinas, } \\
\text { formación en áreas femeninas. }\end{array}$ \\
\hline \multirow[t]{2}{*}{ Dezsó y Ross (2010) } & Positivos & $\begin{array}{l}\text { Diversidad, diferencias de comportamiento directiva, } \\
\text { nuevas ideas y perspectivas. }\end{array}$ \\
\hline & Negativos & $\begin{array}{l}\text { Falta de cohesión, estilos de liderazgo diferentes, } \\
\text { luchas de poder, estereotipo de género, surgimiento } \\
\text { de subgrupos. }\end{array}$ \\
\hline \multirow[t]{3}{*}{ Mensi-Klarbach, 2014} & Social & $\begin{array}{l}\text { Estereotipo de género, segregación vertical y } \\
\text { horizontal, normas de goodmanagement. }\end{array}$ \\
\hline & Organizativo & $\begin{array}{l}\text { Diversidad, cultura organizativa, relaciones de poder, } \\
\text { segregación. }\end{array}$ \\
\hline & Individual & Redes sociales, experiencia, valores. \\
\hline \multirow[t]{4}{*}{ Doubell y Struwig (2014) } & De personalidad & Autoeficiacia, control de uno mismo, autoestima. \\
\hline & Contexto cultural & $\begin{array}{l}\text { Distancia de poder, gestión de la incertidumbre, } \\
\text { individualismo/colectivismo, } \\
\text { masculinidad/feminidad. }\end{array}$ \\
\hline & Organizativos & $\begin{array}{l}\text { Estereotipo de género, estereotipo de liderazgo, falta } \\
\text { de modelos de referencia y mentorización, networks } \\
\text { inaccesibles, inhóspita cultura organizativa. }\end{array}$ \\
\hline & Externos & $\begin{array}{l}\text { Apoyo familiar, apoyo profesional de asociaciones, } \\
\text { iniciativas gubernamentales. }\end{array}$ \\
\hline \multirow[t]{2}{*}{$\begin{array}{l}\text { Pletzer, Nikolova, Kedzior y Voelpel } \\
\text { (2015) }\end{array}$} & Positivos & $\begin{array}{l}\text { Diversidad, diferencias de comportamiento directivo, } \\
\text { nuevas ideas y perspectivas. }\end{array}$ \\
\hline & Negativos & $\begin{array}{l}\text { Falta de cohesión, estilos de liderazgo diferentes, } \\
\text { luchas de poder, estereotipo de género, surgimiento } \\
\text { de subgrupos. }\end{array}$ \\
\hline \multirow[t]{2}{*}{ Moncayo Orjuela y Zuluaga (2015) } & Externas & $\begin{array}{l}\text { Falta de mentorazgo y apoyo a las mujeres, abierta } \\
\text { obstaculización del ascenso por parte de otros } \\
\text { miembros, hostigamiento y quorum laboral } \\
\text { femenino, diferencias salariales de género, ausencia de } \\
\text { modelos de liderazgo. }\end{array}$ \\
\hline & Internas & $\begin{array}{l}\text { Autoestima femenina, miedo al fracaso, falta de } \\
\text { competitividad, desinformación de acceso a cargos } \\
\text { para aplicar. }\end{array}$ \\
\hline
\end{tabular}

Tabla 2. Resumen de clasificaciones de los factores según los autores 
A lo largo del análisis de las clasificaciones se observan una serie de discrepancias. En primer lugar la diferencia entre factores internos y factores externos es muy "débil" en algunas ocasiones. Si bien los factores externos quedan claros pues son ajenos a cualquier organización y a cualquier circunstancia personal, los factores internos no terminan de quedar bien explicados. Agut Nieto y Martín (2007) incluyen como factor interno la falta de autoeficacia y la formación tradicionalmente femenina, mientras que Ramos et al. (2003) incluyen los estereotipos de género y los estilos de liderazgo. Los primeros aluden a factores más de tipo personal, mientras que los segundos se refieren a factores más sociales. Por su parte, Moncayo Orjuela y Zuluaga (2015) y de Anca y Aragón (2007) incorporan contexto personal y falta de autoestima y miedo al fracaso dentro de internos.

Por ello, en nuestra clasificación, hemos considerado necesario eliminar la nomenclatura "factor interno" como tal y lo hemos sustituido por "factor personal" para agrupar los factores que dependen directamente de circunstancias personales e individuales de cada mujer.

Por otro lado, para agrupar los factores que hacen referencia a contexto social como pueden ser los estereotipos de género, las políticas públicas, los distintos roles hemos incorporado la clasificación de "factores sociales".

Por último, el factor organizativo se mantiene por la importancia que tiene y porque todos los autores así lo contemplan; en el caso de los autores que no lo contemplan explícitamente, lo incorporan dentro de externo. En nuestra clasificación se considera una clasificación en sí misma por la importancia que sus factores tienen a la hora de influir en el desarrollo de la carrera profesional de la mujer.

Por ello, este análisis pretende integrar una clasificación de factores en:

1. Factores Personales

2. Factores Organizativos

3. Factores Sociales

\subsection{Factores personales}

Los factores personales se definen como los factores individuales inherentes a la propia persona.

Dentro de esta clasificación tendríamos los factores anteriormente descritos: factor interno, responsabilidad familiar y formación y desarrollo.

En cuanto a la responsabilidad familiar es un hecho indiscutible de satisfacción del individuo (León \& Chinchilla, 2004) y como tal debe enmarcarse dentro de un contexto personal. La literatura estudia la responsabilidad familiar desde un punto de vista individual, de la mujer en cuestión, de su estado civil, número de hijos, edad, tipo de familia etc. (Zabludovsky, 2007; Cuadrado y Morales, 2007; Sarrió, Barberá, Ramos \& Candela, 2002). Por lo que son factores que están ligados directamente con la persona.

En cuanto a la formación y desarrollo, éste constituye un factor también de tipo personal pues es distinta la formación y desarrollo que pueda tener cada persona. Tradicionalmente se hablaba de falta de formación en las mujeres para ocupar puestos directivos, sin embargo esto se ha ido desplazando de barrera hacia favorecedor (Ridgeway, 2001; Pallarès \& Martínez, 1993; de Anca \& Aragón, 2007).

El último factor que se enmarcaría en esta clasificación es el factor interno. Estos son aquellos que se encuentran arraigados a la esfera personal según Moncayo Orjuela y Zuluaga (2015). Estamos hablando de la autoestima, del miedo al al éxito, de la falta de confianza y seguridad (Oplatka, 2006).

Generalmente, todos estos factores vienen recogidos en las clasificaciones de factores dentro de factores de personalidad (Doubell \& Struwig, 2014) o en los factores internos (de Anca \& Aragón, 2007; Moncayo Orjuela \& Zuluaga, 2015; Agut Nieto y Martín, 2007). 


\subsection{Factores organizativos}

Los factores organizativos se definen como todos los factores que se desprenden de la organización. En este sentido, los factores organizativos que se pueden englobar en esta clasificación son el liderazgo, la cultura organizativa, el apoyo organizativo y las redes sociales o de trabajo.

En primer lugar, el factor de liderazgo hace referencia a los diferentes estilos de liderazgo y a las distintas cualidades de hombres y mujeres para liderar (Eagly, 1987). En el ámbito organizativo, el liderazgo es algo descrito como masculino (O’Neil, Hopkins \& Bilimoria, 2008; Eagly, 2007). Es oportuno incluir el liderazgo dentro del factor organizativo porque en esta investigación se analiza el liderazgo desde un punto de vista organizativo y desde la necesidad de analizar como las organizaciones de hoy en día se caracterizan por estilos de liderazgo típicamente masculinos donde el estilo femenino tiene escasa cabida (Yáñez \& Godoy, 2008).

En segundo lugar, la cultura organizativa, conocida como los valores que son compartidos por todos los miembros de la organización y con los que se identifican según Peters, Waterman y Jones (1982), es un elemento organizativo; depende directamente de la organización, por ello está incluida en el factor organizativo. La cultura organizativa solo se puede entender dentro del contexto de la organización; es algo que viene impuesto por la organización.

En tercer lugar, el apoyo organizativo es un factor que se ha extraído de la descripción de apoyo. Dentro de apoyo, , distinguimos entre apoyo organizativo y apoyo externo. Cuando hablamos de apoyo organizativo, nos referimos al apoyo interno que la empresa da a sus miembros, por lo que necesariamente tiene que ser un factor organizativo (Bilimoria \& Piderit, 2007; Ibarra, Carter \& Silva, 2010).

Por último, el factor redes sociales o de contacto son todas las relaciones que se puedan entablar directa o indirectamente relacionadas con el trabajo para poder tener acceso a recursos que repercuten en el progreso de la mujer: ya sea en el salario, en la promoción, en el reconocimiento personal y profesional etc. Estas redes permiten acceso a información y a recursos valiosos para el desarrollo profesional. Son redes que se van tejiendo en el ámbito organizativo, por lo que necesariamente tienen que formar parte del factor organizativo. (Terjesen, 2005; Dezsó \& Ross, 2012).

Según la literatura, en las clasificaciones analizadas, liderazgo, apoyo organizativo, redes sociales y cultura organizativa vienen recogidas como factores organizativos para la mayoría de los autores (Doubell \& Struwig, 2014; de Anca \& Aragón, 2007; Oakley, 2000; Mensi-Klarbach, 2014) o como factores externos (Agut Nieto y Martin, 2007; Moncayo Orjuela \& Zuluaga, 2015; Ramos et al., 2003). En este caso, los autores que identifican estos factores como factores externos lo hacen porque la única clasificación que asumen es factores internos y factores externos.

\subsection{Factores sociales}

Los factores sociales son factores que no dependen de las circunstancias personales ni organizativas. Son factores externos (como así los llaman muchos autores) que vienen marcados por el contexto, las circunstancias, las contingencias del exterior, la sociedad, el mercado, la realidad política etc.

En esta clasificación se incluyen los factores de estereotipo de género y políticas públicas y de conciliación.

Por un lado, según Eagly (1987) el estereotipo de género es la idea que los hombres y las mujeres tienen acerca del otro en función de los roles sociales asumidos por cada uno de ellos y como roles sociales que son, deben tenerse en cuenta en los factores externos o sociales.

Por su parte, las políticas públicas y de conciliación son aquellas regulaciones o recomendaciones establecidas por los gobiernos que a su vez vienen determinadas por las exigencias europeas (Crehuet, et al., 2016). Por ello estas leyes suponen factores impuestos desde fuera, de forma externa.

Según la revisión de la literatura, las iniciativas gubernamentales vienen recogidas como factores externos (Doubell \& Struwig, 2014; Moncayo Orjuela \& Zuluaga, 2015; Agut Nieto \& Martín, 2007) así como los 
estereotipo de género (Ramos et al., 2003; Moncayo Orjuela \& Zuluaga, 2015; Agut Nieto \& Martín, 2007). Para Oakley (2000) el estereotipo de género se incluye dentro de factores culturales o de comportamiento mientras que Mensi-Klarbach (2014) lo incluye como factor social. Por ello, con ánimo de recoger todas las clasificaciones en una misma nomenclatura se ha escogido el nombre "factor social" para poder abarcar la teoría de Oakley (2000) y de Mensi-Klarbach (2014).

Queda por tanto nuestra clasificación resumida en la siguiente tabla (Tabla 3):

\begin{tabular}{|l|l|}
\hline \multirow{2}{*}{ Factores personales } & Responsabilidad familiar \\
\cline { 2 - 2 } & Formación y desarrollo \\
\cline { 2 - 2 } & Factor interno \\
\hline \multirow{4}{*}{ Factores organizativos } & Liderazgo \\
\cline { 2 - 2 } & Cultura organizativa \\
\cline { 2 - 2 } & Apoyo organizativo \\
\cline { 2 - 2 } Factores sociales & Redes de contacto y trabajo \\
\hline & Estereotipo de género \\
\hline
\end{tabular}

Tabla 3. Tipología de los factores

\section{Conclusiones y líneas futuras}

La identificación de tipologías es básica para el desarrollo de teorías y de investigación en las ciencias sociales. La importancia de este trabajo está clara, dado que es necesario categorizar y describir las clasificaciones de los factores para una mayor comprensión de los mismos de cara a proponer soluciones en el ámbito empresarial que permitan romper con el techo de cristal.

Es muy importante establecer tipologías que puedan servir para ser contrastadas empíricamente y así ofrecer soluciones a la problemática que afecta hoy en día a la mujer directiva.

En este trabajo, se han analizado los criterios empleados para clasificar los factores determinantes del desarrollo profesional de la mujer directiva con el fin de proponer una tipología común a todos ellos que pueda servir para reunir una teoría extrapolable para otras investigaciones. Para ello la literatura ha sido debidamente revisada y analizada, mediante una revisión sistemática.

La dificultad de esta investigación se observa en dos sentidos. Por un lado, ha sido difícil elegir los términos o nomenclaturas más apropiadas que recojan el significado de otros nombres empleados por otros autores, dado que cada uno emplea el nombre que estima oportuno. Por otro lado, la búsqueda de artículos en los que se establezca una clasificación de los factores ha sido una tarea muy minuciosa puesto que la mayoría de las investigaciones enumeran y describen los factores uno tras otro sin necesidad de establecer ningún orden o clasificación.

Por tanto, desde un punto de vista teórico, se puede sintetizar la contribución del trabajo en una tipología obtenida en base a una revisión y análisis de la literatura, por lo que está generalmente aceptada y fundamentada por las investigaciones previas. Esta tipología engloba lo mejor lo mejor posible los factores que determinan la carrera profesional de la mujer directiva.

En lo que respecta a las líneas futuras de investigación, está en proceso otro trabajo de investigación que describe detalladamente cada uno de los factores pertenecientes a la tipología aquí propuesta. De forma que sería un trabajo de investigación que confirmase teóricamente la tipología con la descripción minuciosa de cada uno de los factores correspondientes a factores personales, organizativos y sociales. En cuanto a las implicaciones prácticas del trabajo, es imprescindible contrastar esta tipología con un análisis empírico que permita generalizar esta tipología y hablar de taxonomía.

En definitiva, el gap principal que se ha encontrado a lo largo de la revisión de la literatura se centra en la carencia de clasificación. De la selección de 50 artículos, exclusivamente 9 artículos presentan una clasificación. 
Otro gap importante es la falta de uso de una nomenclatura común, dado que por ejemplo, unos autores emplean el término social y otros el término externo para hacer referencia a factores que no dependen ni de la organización a la que la mujer pertenezca ni a la propia mujer.

Finalmente, también este trabajo supone implicaciones desde un punto de vista empresarial ya que puede servir de referencia para directivos empresariales cuyo objetivo sea fomentar el papel de la mujer en puestos de responsabilidad dentro de las organizaciones, lo que le permitirá reconocer los factores que determinan su desarrollo y actuar en su favor.

\section{Declaración de conflictos de interés}

Los autores no han declarado posibles conflictos de interés por lo que respeta a la investigación, la autoría y/o la publicación de este artículo.

\section{Financiación}

Los autores no recibieron ningún soporte financiero para la investigación, la autoría y/o la publicación de este artículo,

\section{Referencias}

Acker, J. (2006). Inequality regimes: Gender, class, and race in organizations. Gender \& society, 20(4), 441-464. https://doi.org/10.1177/0891243206289499

Aguirre, Z., \& Martínez, M.P. (2006). Influencia de la situación laboral en el ajuste familia- trabajo. Mapfre Medicina, 17(1), 14-24. Retrieved from: http://www.mapfre.com/fundacion/html/revistas/medicina/v17n1/pag02 $02 \mathrm{res} . \mathrm{html}$

Agut Nieto, S., \& Martín Hernández, P. (2007). Factores que dificultan el acceso de las mujeres apuestos de responsabilidad: una revisión teórica. Apuntes de Psicología, 25(2), 201-214. Retrieved from: https: $/ /$ dialnet.unirioja.es $/$ servlet $/$ articulo? codigo $=2350842 \&$ info $=$ resumen\&idioma $=$ SPA

Álvarez, A., \& Gómez, I.C. (2010). Conflicto trabajo-familia, en mujeres profesionales que trabajan en la modalidad de empleo. Pensamiento Psicológico, 9(16), 89-106. Retrieved from: http://www.redalyc.org/articulo.oa? $\underline{\mathrm{id}=80118612006}$

Belzunegui Eraso, A. (2008). Teletrabajo en España, acuerdo marco y administración pública. Revista Internacional de Organizaciones (RIO), 1, 129-148. https://doi.org/10.17345/rio1.129-148

Berkovich, M., Leimeister, J.M., \& Krcmar, H. (2011). Requirements engineering for product service systems. Business \& Information Systems Engineering, 3(6), 369-380. https://doi.org/10.1007/s12599-011-0192-2

Bilimoria, D., \& Piderit, S.K. (2007). Handbook on women in business and management. Cheltenham: Edward Elgar. https://doi.org/10.4337/9781847204134

Bozart, C., \& McDermott, C. (1998). Configurations in manufacturing strategy: A review and directions for future research. Journal of Operations Management, 16(4), 427-439. https://doi.org/10.1016/S0272-6963(98)00022-9

Cánovas, A., Aragón, J., \& Rocha, F. (2005). Las políticas de conciliación de la vida familiar y laboral en las Comunidades Autónomas. Cuadernos de Relaciones Laborales, 23(1), 73-93.

Cousté, N.L. (1997). La tipología de estrategias de Miles y Snow: Un estudio aplicando una escala multiítem 1. Revista Europea de Dirección y Economía de la Empresa, 6(2), 33-44.

Cuadrado, I. (2003). ¿Emplean hombres y mujeres diferentes estilos de liderazgo? Análisis de la influencia de los estilos de liderazgo a los puestos de dirección. Revista de Psicología Social, 18, 283-307.

https://doi.org/10.1174/021347403322470864 
Cuadrado, I., \& Morales, J. (2007). Algunas claves sobre el techo de cristal en las organizaciones. Revista de Psicologia del Trabajo y de las Organizaciones, 23, 183-202.

De Anca, C., \& Aragón, S. (2007). La mujer directiva en España: Catalizadores e inhibidores en las decisiones de trayectoria profesional. Academia, Revista Latinoamericana de Administración, (18), 45-63.

Dess, G.G., Newport, S., \& Rasheed, A.M. (1993). Configuration research in strategic management: Key issues and suggestions. Journal of Management, 19(4), 775-795. https://doi.org/10.1177/014920639301900403

Dezsó, C.L., \& Gaddis Ross, D. (2012). Does Female Representation in Top Management Improve Firm Performance? A Panel Data Investigation. Strategic Management Journal, 33, 1072-1089.

https://doi.org/10.1002/smj.1955

Directiva del Consejo Europeo de 9 de febrero de 1976 relativa a la aplicación del principio de igualdad de trato entre hombres y mujeres en lo que se refiere al acceso al empleo, a la formación y a la promoción profesionales, y a las condiciones de trabajo (76/207/CEE).

Directiva del Consejo Europeo de 10 de febrero de 1975 relativa a la aproximación de las legislaciones de los Estados Miembros que se refieren a la aplicación del principio de igualdad de retribución entre los trabajadores masculinos y femeninos (75/117/CEE)

Doty, D., \& Glick, W. (1994). Typologies as a Unique Form of Theory Building: Toward Improved Understanding and Modeling. The Academy of Management Review, 19(2), 230-251. Retrieved from: http://www.jstor.org/stable/258704

Doty, D.H., Glick, W.H., \& Huber, G.P. (1993). Fit, equifinality, and organizational effectiveness: A test of two configurational theories. Academy of Management journal, 36(6), 1196-1250. https://doi.org/10.2307/256810

Doubell, M., \& Struwig, M. (2014). Perceptions of factors influencing the career success of professional and business women in South Africa. South African Journal of Economic and Management Sciences, 17(5), 531-543. https://doi.org/10.4102/sajems.v17i5.514

Durán, M.A. (ed.) (1997). Las bases sociales de la economía española. Valencia: Universidad de Valencia.

Eagly, A.H. (1987). Reporting sex differences.

Eagly, A.H. (2007). Female leadership advantage and disadvantage: Resolving the contradictions. Psychology of Women Quarterly, 31, 1-12. https://doi.org/10.1111/j.1471-6402.2007.00326.x

Eagly, A., \& Carli, L. (2007). Women and the Labyrinth of Leadership. Harvard Business Review, 85, 63-71.

Festing, M., Knappert, L., \& Kornau, A. (2015). Gender-specific preferences in global performance management: an empirical study of male and female managers in a multinational context. Human Resource Management, 54(1), 55-79. https://doi.org/10.1002/hrm.21609

Geraldi, J., Maylor, H., \& Williams, T. (2011). Now, let's make it really complex (complicated) A systematic review of the complexities of projects. International Journal of Operations \& Production Management, 31(9), 966-990. https://doi.org/10.1108/01443571111165848

Guirao, C. (2011). Nuevas formas de relación trabajo productivo y sociedad: La conciliación de la vida familiar y laboral. Prisma Social, 6(Junio, 2011), 1-27. Retrieved from:

http://www.isdfundacion.org/publicaciones/revista/numeros/6/secciones/tematica/05-nuevas-formas-relaciontrabajo-productivo.html

Hafsteinsdóttir, T.B., van der Zwaag, A.M., \& Schuurmans, M.J. (2017). Leadership mentoring in nursing research, career development and scholarly productivity: A systematic review. International Journal of Nursing Studies, 75, 21-34. https://doi.org/10.1016/j.ijnurstu.2017.07.004

Hambrick, D., \& Mason, P. (1984). Upper Echelons: The Organization as a Reflection of Its Top Managers. The Academy of Management Review, 9(2), 193-206. Retrieved from:http://www.jstor.org/stable/258434 
Hancock, M.G., \& Hums, M.A. (2016). A "leaky pipeline"?: Factors affecting the career development of seniorlevel female administrators in NCAA Division I athletic departments. Sport Management Review, 19(2), 198-210. https://doi.org/10.1016/j.smr.2015.04.004

Hawley, E., Torres, D., \& Rasheed, S. (1998). Assessing barriers to women's career adjustment. Journal of Career Assessment, 6(4), 449-479. https://doi.org/10.1177/106907279800600406

Hopkins, M., \& Bilimoria, D. (2008). Social and emotional competencies predicting success for male and female executives. Journal of Management Development, 27, 13- 35. https://doi.org/10.1108/02621710810840749

Ibarra, H., Carter, N.M. \& Silva, C. (2010). Why men still get more promotions than women. Instituto de la mujer. Estadísticas 2005 y 2006. Retrieved from: http://www.mtas.es/mujer/mujeres/cifras/empleo/situacion laboral.htm

Kotha, S., \& Vadlamani, B. (1995). Assessing Generic Strategies: An Empirical Investigation of Two Competing Typologies in Discrete Manufacturing Industries. Strategic Management Journal, 16(1), 75-83. https://doi.org/10.1002/smj.4250160108

Kumra, S. (2010). Exploring Career "choices" of work-centred women in a professional service firm. Gender in Management: An International Journal, 25 (3), 227-243. https://doi.org/10.1108/17542411011036428

León, C., \& Chinchilla, N. (2004). Directivas en la empresa: Criterios de decisión y valores femeninos en la empresa. Documento de trabajo del IESE.

Lucia-Casademunt, A.M., Ariza-Montes, J.A., \& Morales-Gutiérrez, A. C. (2013). La implicación emocional de los empleados de banca en Europa. Universia Business Review, (38), 32-49.

Marín-García, Juan A., \& Martínez Tomás, J. (2016). Deconstructing AMO framework: A systematic review. Intangible Capital, 12(4), 1040-1087. https://doi.org/10.3926/ic.838

Martínez-Pérez, M.D., \& Osca, A. (2004). El éxito profesional desde una perspectiva de género: Propuesta de un modelo. Revista de Psicología General y Aplicada, 57(2), 193-208. Número monográfico "La psicología y el acceso de la mujer a la función directiva" (Coordinadores: J. F. Morales e I. Cuadrado).

Mensi-Klarbach, H. (2014). Gender in top management research: Towards a comprehensive research framework. Management Research Review, 37(6), 538-552. https://doi.org/10.1108/MRR-03-2013-0066

Meyer, A.D., Tsui, A., \& Hinings, C. (1993). Guest Co-editors' Introduction: Configurations Approaches to Organisational Analysis. Academy of Management Journal, 36(6), 1175-1195. https://doi.org/10.2307/256809

Miller, D. (1996). Configurations Revised. Strategic Management Journal,17, 505-512. https://doi.org/10.1002/ (SICI)1097-0266(199607)17:7<505::AID-SMJ852>3.0.CO;2-I

Moncayo Orjuela, B.C., \& Zuluaga, D. (2015). Liderazgo y género: Barreras de mujeres directivas en la academia. Pensamiento \& Gestión, (39), 142-177.

O’Neil, D.A., Hopkins, M.M., \& Bilimoria, D. (2008), Women's careers at the start of the twenty-first century: Patterns and paradoxes. Journal of Business Ethics, 80(4), 727-743. https://doi.org/10.1007/s10551-007-9465-6

Oakley, J.G. (2000). Gender-based Senior Barriers to Management Positions: Understanding Scarcity of Female CEOs. Slideheaven, 27(4), 321-334.

Oplatka, I. (2006). Women in educational administration within developing countries: Towards a new international research agenda. Journal of Educational Administration, 44(6), 604-624.

https://doi.org/10.1108/09578230610704819

Pallarès, S., \& Martínez, M. (1993). Imágenes de la Dirección: Metáforas de la función directiva desde la propia dirección. Revista de Psicología, 4, 27.

Pateli, A.G., \& Giaglis, G.M. (2004). Framework for analyzing eBusiness. European Journal of Information Systems, 13, 302-314. https://doi.org/10.1057/palgrave.ejis.3000513 
Peters, T.J., Waterman, R.H., \& Jones, I. (1982). In search of excellence: Lessons from America's best-run companies. New York: Harper \& Row.

Pletzer, J.L., Nikolova, R., Kedzior, K.K., \& Voelpel, S.C. (2015). Does Gender Matter? Female Representation on Corporate Boards and Firm Financial Performance - A Meta-Analysis. Plos One, 10(6), e0130005.

https://doi.org/10.1371/journal.pone.0130005

Ramos López, M.A., Barbera, E., \& Sarrió Catalá, M. (2003). Mujeres directivas, espacio de poder y relaciones de género. Anuario de Psicologia, 34, 267-278.

Richardson, P.R., Taylor, A.J., \& Gordon, J.R.M. (1985), A Strategic Approach to Evaluating Manufacturing Performance. Interfaces, 15(6), 15-27. https://doi.org/10.1287/inte.15.6.15

Ridgeway, C.L. (2001). Gender, status, and leadership. Journal of Social Issues, 57(4), 637-655. https://doi.org/10.1111/0022-4537.00233

Rincón, V., González, M., \& Barrero, K. (2017). Women and leadership: Gender barriers to senior management positions. Intangible Capital, 13(2), 319-386. https://doi.org/10.3926/ic.889

Sabater Fernández, M.C. (2014). La interacción trabajo-familia. La mujer y la dificultad de la conciliación laboral. Lan harremanak: Revista de relaciones laborales, 30(30), 163-198. Retrieved from: http:/ $/$ dialnet.unirioja.es $/$ servlet $/$ articulo?codigo $=5029809 \&$ info $=$ resumen\&idioma $=E N G$

Sarrió, M., Barberá, E., Ramos, A., \& Candela, C. (2002). El techo de cristal en la promoción profesional de las mujeres. Revista de Psicología Social, 17 (2), 167-182. https://doi.org/10.1174/021347402320007582

Selva, C., Sahagún, M.A., \& Pallarès, S. (2011). Estudios sobre trayectoria profesional y acceso de la mujer a cargos directivos: Un análisis bibliométrico. Revista de Psicología del Trabajo y de las Organizaciones, 27(3), 227-242. https://doi.org/10.5093/tr2011v27n3a6

Sullivan, S.E., \& Mainiero, L. (2008). Using the kaleidoscope career model to understand the changing patterns of women's careers: Designing HRD programs that attract and retain women. Advances in Developing Human Resources, 10(1), 32-49. https://doi.org/10.1177/1523422307310110

Swanson, J., \& Witke, M. (1997). Theory into practice in career assessment for women: Assessment and interventions regarding perceived barriers. Journal of Career Assessment, 5, 443-462.

https://doi.org/10.1177/106907279700500405

Terjesen, S. (2005). Senior women managers' transition to entrepreneurship Leveraging embedded career capital. Career Development International, 10, 246-259. https://doi.org/10.1108/13620430510598355

Terjesen, S., \& Singh, V. (2008). Female presence on corporate boards: A multi-country study of environmental context. Journal of Business Ethics, (83), 55-63. https://doi.org/10.1007/s10551-007-9656-1

Tomás, M., \& Guillamon, C. (2009). Las barreras y los obstáculos en el acceso de las profesoras universitarias a los cargos de gestión académica. Revista de Educación, 350, 253- 275.

Webster, J., \& Watson, R.T. (2002). Analyzing the past to prepare for the future: Writing a literature review. MIS quarterly, 26(2), 13-23.

Wirth, L. (2001). Breaking through the glass-ceiling: women in management. Geneva: International Labour Office.

Yáñez, S., \& Godoy, L. (2008). Effects of gender images and stereotypes on female E\&T research careers in higher education in Chile. En A.S. Godfroy-Genin (Ed.), Women in engineering and technology research. Proceedings of the PROMETEA Conference. 26-27 October 2007, Paris. Züricb: Lit Verlag.

Zabludovsky, G. (2007). México: Mujeres en cargos de dirección del sector privado. Academia. Revista Latinoamericana de Administración, 38, 9-26. 
Intangible Capital, 2018 (www.intangiblecapital.org)

\section{(c) (P)}

Article's contents are provided on an Attribution-Non Commercial 4.0 Creative commons International License. Readers are allowed to copy, distribute and communicate article's contents, provided the author's and Intangible Capital's names are included. It must not be used for commercial purposes. To see the complete license contents, please visit https://creativecommons.org/licenses/by-nc/4.0/. 